Document downloaded from:

http://hdl.handle.net/10251/74208

This paper must be cited as:

Lo-lacono-Ferreira, VG.; Torregrosa López, Jl.; Capuz-Rizo, SF. (2016). Use of life cycle assessment methodology in the analysis of ecological footprint assessment results to evaluate the environmental performance of universities. Journal of Cleaner Production. 133:45-53. doi:10.1016/j.jclepro.2016.05.046.

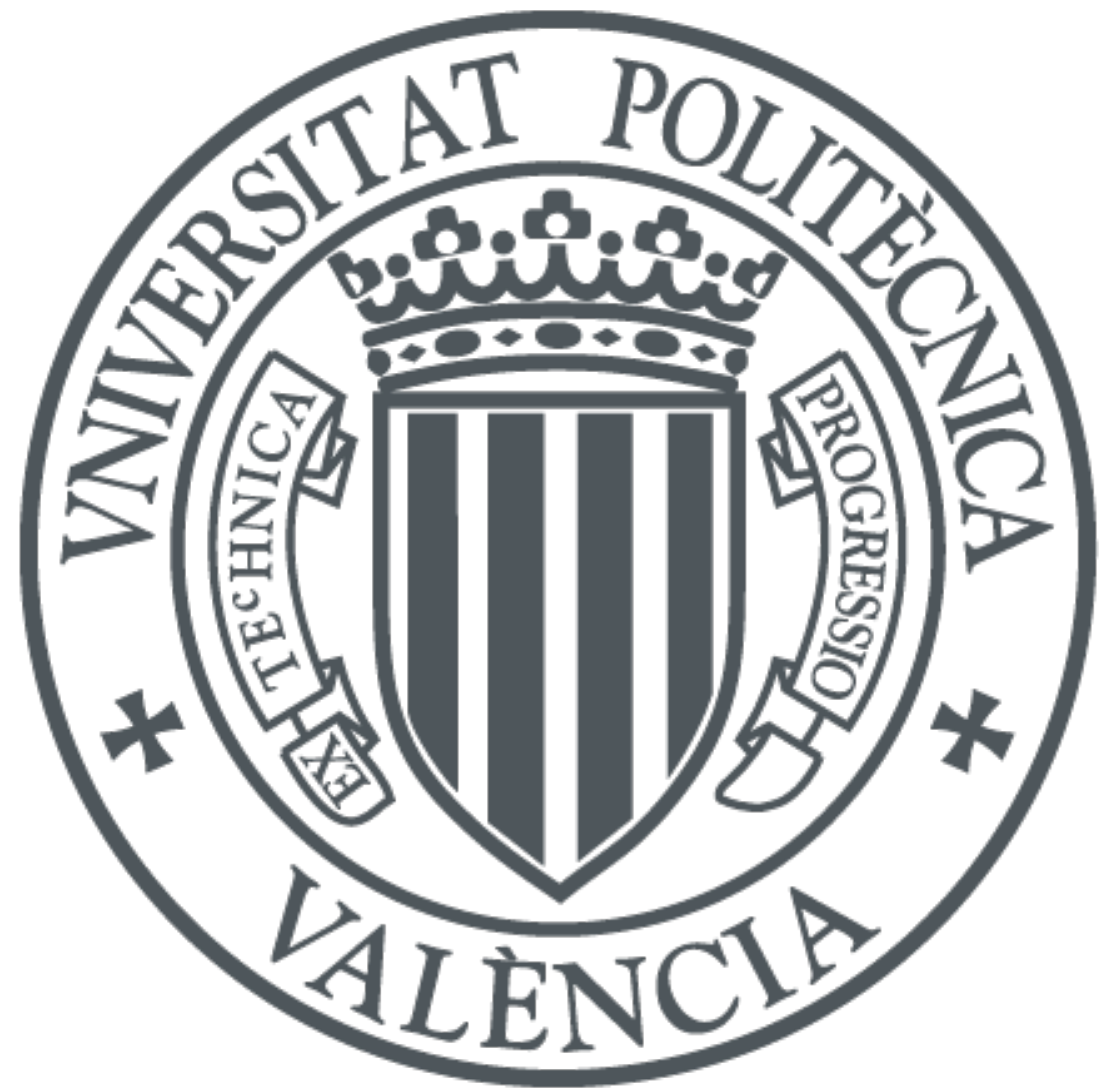

The final publication is available at

http://dx.doi.org/10.1016/j.jclepro.2016.05.046

Copyright Elsevier

Additional Information 


\section{Use of Life Cycle Assessment methodology in the analysis of Ecological Footprint Assessment results to evaluate the environmental performance of universities}

Lo-lacono-Ferreira, Vanesa Gladys ${ }^{a}$; Torregrosa-López, Juan Ignaciob; Capuz-Rizo, Salvador F. ${ }^{c}$.

a Universitat Politècnica de València, PI. Ferrándiz y Carbonell, s/n 03801 Alicante, Spain.valoia@epsa.upv.es [corresponding author]

${ }^{b}$ Universitat Politècnica de València, PI. Ferrándiz y Carbonell, s/n 03801 Alicante, Spain. jitorreg@iqn.upv.es

c Universitat Politècnica de València, Camino de Vera, s/n E-46022 Valencia, Spain. scapuz@dpi.upv.es

\section{Abstract}

The assessment of the environmental performance of an organization is an essential part of the decision-making process of an Environmental Management System. Having robust indicators enables a reliable assessment. The Ecological Footprint Assessment is used in different types of organizations, including universities. Its ability to clearly communicate over-consumption by using a land-base unit is an advantage when involving the university community in achieving better environmental performance. However, its lack of standardization makes it difficult to use as an indicator. It is believed that Life Cycle Assessment offers a framework with which to standardize the Ecological Footprint Assessment. In this paper, an Ecological Footprint Assessment considering Life Cycle Assessment methodology is developed as a case study for Universitat Politècnica de València. Findings regarding the critical decisions of the methodology are compared with 23 Ecological Footprint Assessments of universities using a Life Cycle Assessment framework. Only 26\% of the studies analyzed reference the Life Cycle Assessment methodology. Critical decisions such as defining a Functional Unit were relevant but not standardized, while the definition of the product system was the most standardized and homogeneous decision. The difficulty of gathering information when Environmental Management Systems are not available makes the Ecological Footprint Assessment a weak indicator. Nevertheless, results show that Life Cycle Assessment can guide an Ecological Footprint Assessment methodology where comparability and reliability is possible.

Keywords: Life Cycle Assessment, Ecological Footprint Assessment, Universities, Scope, Functional Unit, System Boundaries

Acronyms list

EFA: Ecological Footprint Assessment

EMAS: Eco-Management and Audit Scheme 
EMS: Environmental Management System

FU: Functional Unit

gha: Global hectares

LCA: Life Cycle Assessment

SB: System Boundaries

UPV: Universitat Politècnica de València

\section{Introduction}

Sustainability is receiving increasing attention (Disterheft et al., 2012). Since the Rio Summit (UNEP, 1992), governments of many countries have agreed on the importance of improving their activities to attain a sustainable future that satisfies our current needs without compromising future generations (Brundtland Commission, 1987). The scope is clearly global and aims towards a sustainable society with regards to environmental, economic and social systems. It is necessary to integrate environmental and social aspects into economic aspects to overcome resistance to change (Lozano, 2006). Just as important is the need to improve and report the status of sustainability (Joseph, 2012). The reporting of sustainability actions taken by universities is well studied, and its relevance is established (Lozano et al., 2013; Alonso-Almeida et al.,2015; Ceulemans et al., 2015). Strategies to improve sustainability have also been discussed. The signing of declarations, charters and initiatives are strongly related to institutional efforts to contribute to sustainable development (Lozano, 2015).

Nevertheless, some tools are needed to help management improve sustainability. At a regional level, sustainable development can be incorporated into the planning framework (Roseland, 2000). At a smaller scale, such as in organizations, buildings, small areas and processes, the solution could be linked to a management system. The scope of this study is a complex organization, the university.

To manage organizations in a sustainable way, it is necessary to know how well these systems are performing. Monitoring interactions between system agents is also important. Many parameters, including emissions, resource and energy consumption and usage patterns, must be measured. These facts have motivated the development of systems that gather such information, i.e., Environmental Management Systems (EMS). An EMS is a set of systematic, planned and documented processes that manage the environmental aspects of an organization (Klassen \& McLaughlin, 1996; Seiffert \& Loch, 2005). An EMS can be the decision-making tool with which to guide an organization towards sustainable development. 
To be rigorous in this decision-making process, it is necessary to assess the performance of institutional efforts towards sustainability. These efforts need to be assessed and analyzed individually and together to view their synergies (Azqueta \& Delacamara, 2006). Considering up and down streams, as well as the use phase, is as important as having a global view of the organization's performance. Although all three areas of sustainability - environmental, economic and social - are equally important, this work focuses on the environmental aspects of sustainability.

The environmental impact of universities is significant considering that universities have been compared to small cities or large commercial areas due to their energy and resource consumption (Alshuwaikhat \& Abubakar, 2008; Viebahn, 2002). The complexity of universities has been established (Denman, 2009). Universities have an ethical responsibility to societal development; therefore, they have a responsibility to lead the way towards a more sustainable society (Viebahn, 2002). Improving the assessment of campuses' environmental performance can foster action in other public or private institutions and turn universities into role models or lighthouses.

EMS has been progressively adopted as a management tool for the improvement of campuses' environmental performance (Clarke \& Kouri, 2009). To assess universities' environmental strategies at different scales, tools such as Life Cycle Assessment (LCA), Carbon Footprint and Ecological Footprint Assessment (EFA) have been adopted (Alshuwaikhat \& Abubakar, 2008).

In recent years, some studies have used the EFA to assess several areas and functional units of universities. Some EFAs have been performed at universities around the world with the following three main goals: (1) to assess the university's ecological impact, (2) to support policy planning and (3) to raise awareness among the university community (Lambrechts \& Van Liedekerke, 2014). Studies of different aspects of EFA models have also been published. Nunes et al. (2013) analyzed the influence of uncertainty in the EFA with regards to university campuses.

According to the definition of LCA, there is a very close relationship between EFA and LCA, and some authors explicitly defend the necessity of standardized and detailed LCA studies to support the calculation of specific impacts accounted for in EFA (Castellani \& Sala, 2012). From a methodological point of view, LCA offers an opportunity to analyze and eliminate many of the drawbacks of EFA. LCA can also define the functional unit and scope. In LCA, the Global Warning Potential Category can be considered differently by assessing absorbing waste flows in a given year for a defined population (Finkbeiner, 2009). This paper explores the possibility of using EFA as an aggregated indicator where the objectives and scope have been defined according to LCA philosophy.

The purpose of this work is to analyze some of the most significant EFAs of universities published from an LCA point of view and to reach informed decisions in the use of this 
indicator to assess universities' environmental aspects. A total of 23 EFA studies published between 2001 and 2014 were analyzed. The aim of this study is (1) to study the differences among methodologies that practitioners are likely to use with the EFA at universities; and (2) identify, from a methodological point of view based on LCA, critical points and specific drawbacks.

\section{Literature review of LCA and EFA as performance tools for universities}

Different ways of assessing environmental performance have been developed ( $M$. Herva et al., 2011; Herva et al., 2008). The LCA technique was developed to better understand and address environmental impacts associated with products and services (International Organization for Standardization, 2006a). Due to its strict definition, LCA is one of the most accepted tools for the study and measurement of environmental impacts associated with products and services.

It might be considered applying LCA directly on universities. LCA has temporal and geographical variability, a defined area and a given temporary variable. It is probable what has recently led to the development of an Organizational Life Cycle Assessment (OLCA) procedure.

However, LCA may be the key with which to assess the environmental performance standards of an organization. As evidenced by the development of ISO 14072, consensus is needed to apply LCA at universities (Finkbeiner et al., 2014). ISO 14072 is a norm with which to develop an OLCA as a procedure to compile and evaluate inputs, outputs and potential environmental impacts of an organization. Principles and requirements for ISO 14072 are extremely similar to ISO 14040 and 14044 . It must be noted that OLCA is not recommended for comparison purposes (Martínez-Blanco et al., 2015; UNEP, 2015). Issues related to comparison purposes will be discussed further in this paper.

EFA has been proposed as a measure of ecological impact (Herva et al., 2008; Rees \& Wackernagel, 1996; Wackernagel \& Rees, 1997). The EFA is an aggregated measure that expresses results in terms of the biophysical limits of the resources used. The EFA acts as a strong statement in reports to identify and communicate potential sources of unsustainability to society and to political and corporate decision-makers (Wiedmann \& Barrett, 2010).

The EFA results represent the amount of biologically productive land and water area required to provide resources and assimilate waste produced by a given entity (Conway et al, 2008; Wiedmann \& Barrett, 2010). It is measured in global hectares (gha). A gha represents a hectare of land with productivity equal to that of world average. A hectare is a dimension that is easy to understand and compare. The original EFA methodology was intended for use in land areas such as continents or countries. 
Modifications of this methodology have been applied to other systems such as cities, companies, associations and universities (Galli et al., 2012; Herva et al., 2008;

Wiedmann \& Barrett, 2010). When the EFA is applied to these types of systems, the study highlights consumption, energy use and waste generation. However, when countries or regions are studied, the EFA takes a different approach by comparing land activity with land biocapacity.

Several studies highlight strengths and weaknesses of EFA as an indicator. According to Wiedmann \& Barrett (2010), weaknesses include a lack of scientific rigor in the assessment. Other weaknesses include its inadequacy to make conclusions about environmental policies and its limitation of assessing only issues related to global warming or biocapacity. The ability to communicate urgency of required actions is a strength of the EFA (Wiedmann \& Barrett, 2010). Lambrechts \& Van Liedekerke (2014) considered the EFA as a method to translate the complexity of ecological pressure into an understandable framework, although their results should be carefully interpreted to take into account estimations and critical reflections.

From the point of view of some authors such as Van den Bergh (2010), the EFA does not include all relevant human impacts on the environment, including emissions of toxic substances, water pollution, noise, acid rain, ozone layer depletion, fragmentation of ecosystems due to infrastructure and biodiversity loss. Along the same lines, Herva et al. (2011) questioned the use of the biocapacity concept when EFA is applied to an industry and the difficulty of defining the administrative boundaries of a company. Herva et al. (2010) also criticized EFA for not taking into consideration toxic and hazardous pollutant wastes.

Several studies have shown the usefulness of LCA in assessing the environmental performance of products and services (Hertwich, 2005). The three main components of LCA that contribute to the integrity of the analysis are (1) the determination of processes involved in the life cycle of a product, (2) the determination of environmental pressures (e.g., emissions, use of resources) produced in each process and (3) the assessment of environmental impacts and aggregation of the impact indicators. The ISO 14040 standard for LCA defines the first two steps as inventory analysis and the third step as impact assessment. ISO defines two additional procedural steps, which are goal and scope definition (i.e., planning the LCA) and interpretation (i.e., discussion and conclusions) (Hertwich, 2005).

\section{METHODS}

The purpose of this study is to obtain a better understanding of the results of EFA at universities by applying an LCA framework. We are also interested in comparing studies and the reason why each university decided to use the EFA. 
In this study, the EFA of universities was rigorously compared with LCA foundations and standards. As a consolidated methodology due to its path, ISO 14040 and 14044 are considered the references for this study for LCA concepts. ISO 14072 particularities are also considered as much as possible.

This research analyzes whether different critical decisions are highlighted and how those decisions affect the final result and comparability. In addition, an EFA case study has been compared with a range of diverse studies that have assessed the critical decision parameters required of practitioners.

Given the strengths and weaknesses of EFA, a deep analysis using an LCA framework has shed light on the difficulties in its use as an environmental indicator at universities. We believe that a rigorous study of the use of EFA at universities will ensure transparency and comparability of results.

The analysis can be summarized in the following steps:

1) Definition of the critical decision in general LCA methodology is based on LCA documentation and publications and, in particular, on ISO14040 and ISO14044.

2) Development of a complete case study that is as comprehensive as possible. This case study has been developed for Universitat Politècnica de Valènica (UPV) in Spain. UPV EMAS EMS inspired this research due to its large volume of data that has been used in this step. Data are regularly published in the annual environmental memory of UPV and was extracted and organized prior to assessment. Full details of UPV's structure and UPV EMAS EMS implementation can be found in "EMAS as environmental management system for university campuses" (Torregrosa-López et al., 2016). High-quality data are essential for a robust EFA.

The EFA of UPV has been developed using classical methodologies with some underlying principles of LCA. The following FUs were considered in light of UPV statutes and the UPV mission:

- Students, who are part of the UPV's teaching mission

- Articles published, which is a component of UPV's research mission

- Patents developed, which is part of UPV's knowledge transfer mission

- The university community, which represents a more general FU

This process has been thoroughly documented, the data have been exhaustively analyzed, and critical points have been listed.

3) Studies assessing the use of EFA by universities has been analyzed. Studies of the use of EFA of universities published between 2001 and 2014 were gathered and assessed. When available, journal articles were preferred. Other sources such as web pages were considered when the information 
was relevant due to the type of institution or scope of the study. All Spanish universities with available data were included in the study to obtain an additional local comparison for our UPV case study. Information was obtained from the results and methods of each study document. The analysis was performed using comparative tables. Special attention was given to highlighted decisions detected in Step 1. If more than one study was available for a particular university and all decisions were the same in all studies, only the last study was considered.

In section 4, differences between the case study and the literature were assessed, as well as their omissions and the effect on the final results. The most critical have been highlighted and matched with the critical points found in the case study.

Throughout the study, the relationship between the motivations for the use of EFA in the functional unit and scopes considered in the assessment was sought.

\section{RESULTS AND DISCUSSION}

The results of each step of the proposed research approach are presented and discussed below.

\subsection{Step 1. Definition of the specific decision to consider in general LCA methodology}

One of the most mature and robust methodologies for environmental assessment is that proposed for LCA. The maturity of this methodology is evidenced by its use in widely known ISO standards (International Organization for Standardization, 2006a; International Organization for Standardization, 2006b). Based on this, the definition of the specific decision to consider in general LCA methodology (Step 1) was developed.

In the initial stage of an environmental assessment, practitioners must define a set of elements that will configure the way the LCA is developed. These elements will decide how the results are interpreted. Documenting this information is critical for evaluating the adequacy of the assessment and for comparability purposes. Despite the new standards developed for assessing organizations with ISO 14072 mentioned above, they are not recommended for comparability purposes, and we believe it is important in the future to evaluate the possibility of using ISO 14040 and ISO 14044 or ISO 14072. Comparing organizational assessments of environmental actions may be extremely useful, as stakeholders can learn not only from their own experience but also from the experience of similar organizations. Requirements and guidelines of ISO 14044:2006 (International Organization for Standardization, 2006b) highlight the characteristics needed to perform such an analysis. In particular, section 4.2.3.7 of ISO 14044:2006 specifies which decisions can be critical. The main critical decision points that have been detected are (a) the product system to be studied, (b) the functional unit (FU), (c) 
the system boundary (SB), (d) allocation procedures, (e) Life Cycle Impact Assessment (LCIA) methodology and types of impacts and ( $f$ ) data quality requirements. All other decisions are either case-study specific or do not impact the final result as much as its communication.

The product system is the first piece to be defined. The definition of product system includes all processes that compose the object of study, which in this case is the university.

The FU is defined by ISO 14044:2006 as the parameter that quantifies performance of a product system for use as a reference. ISO 14072 replaces the concept of FU with the concept of reporting unit (RU). The RU is defined as the parameter that quantifies performance expression of the organization to be used as a reference. The main difference between FU and RU is the product system or organization instead of the product or service. As ISO 14072 had not yet been published when the studies included in this research were published, for practical purposes, FU is used as the parameter that quantifies performance expression to be used as a reference.

The SB depends on the subject and the intended use of the study according to the ISO 14044:2006 definition. The SB defines those unit processes as part of the product system that is considered for the study. ISO 14072:2014 suggests a definition of SB considering a process-based approach and the additional operations of the organization. As a complex organization, university processes are diverse, and some might not be easy to define in terms of in/out balance, i.e., teaching. However, processes such as teaching and research should be considered because they represent the mission of the organization.

Allocation is the process by which inputs and outputs are assigned to the product system under study. When the product system is the university as a whole, no allocation procedure is required. However, if, for example, one wants to assess the environmental impact of teaching separately from other university processes, an allocation procedure must be defined.

LCIA methodology aims to understand the significance and magnitude of the environmental impacts of the product system according to ISO 14044:2006. When analyzing the EFA in this study, special attention has been paid to references to a LCIA methodology or a definition of types of impacts considered.

Data quality requirements shall be specified according to ISO 14044:2006, and there were no changes in ISO 14072:2014. Requirements to consider include the following: (a) time-related coverage, (b) geographical coverage, (c) technological coverage, (d) precision, (e) completeness, (f) representativeness, (g) consistency, (h) reproducibility, (i) source of the data and (j) uncertainty of the information. For a detailed definition of each requirement, see section 4.2.3.6 of ISO 14044:2006. 


\subsection{Step 2. Develop a complete case study}

A complete EFA was developed for UPV that paid particular attention to the critical decisions detected (Step 2) that helped structure the assessment and provide a framework for the study. In this section, each critical decision is described following ISO steps.

\subsubsection{Definition of goals, scope, FU, SB and data requirements}

In this step, a complete EFA was performed for UPV. The definition of the product system as the university was clear from the beginning of the study, as mentioned in Step 1.

Defining an FU was one of the first problems to be solved. The FU must reflect the mission or function of the university, according to the ISO 14040 definition, and quantify the university's performance. UPV's mission is defined in the University Statements and contains the following three main processes: teaching, research and knowledge transfer. Although it may be logical to assume that the missions of most universities include these three concepts, there are endless details that must be considered to build an algorithm to reflect them. Integrating these three functions in only one parameter seems arbitrary. Considering that the FU definition will affect comparability with other studies and that all universities have students, the teaching mission is important. Students differ in the amount of time they dedicate to their studies. To obtain homogeneity of the FU, an equivalent student (eqst) unit was defined as a student with full dedication to the university in terms of the academic calendar. The results are biased by this choice and have to be carefully analyzed when compared.

The first approach to the case study used main processes mentioned above to define the SB of the study. Although they are difficult to define in terms of input/output, the analysis of sub-processes such as "teacher offering a certain class" was considered in building the assessment. However, the complexity of the analysis due to this process itself, i.e., for each class, the professor takes a different route between the office and the classroom, made us reconsider the definition of the SB. This route can differ by the day of the week and the professor's previous activity each day. The same is true for each student in the class. For a university with more than 30 undergraduate programs, more than 70 graduate programs and 13 schools or faculties, assessing each class's particularities seems nearly impossible without a full-time team dedicated to gathering complete information using a specific structure. SB was ultimately established from an infrastructure point of view considering three campuses.

The data requirement was also a challenge, and two considerations were made. When considering the data represented by each environmental aspect, quality requirements were easy to define due to the EMS verified by UPV's EMAS. The EMS collects yearly 
environmental information for all environmental aspects except procurement. The selection of the environmental aspect is discussed below in the $\mathrm{LCl}$ section.

The main quality requirement becomes evident when the study requires conversion factors to assess the EFA. The conversion factors needed to convert consumption and generation information, infrastructure data and mobility data to environmental impact units in terms of either emissions or global hectares (gha) is of inadequate quality. Relations between the selected sources are shown in Table 1 in the LCIA sub-section. For example, there is a detailed study of the environmental impact of yearly electric energy generation in Spain that can be used to assign a value to this environmental aspect (WWF, 2015). It is important that the energy impact is assessed considering the local energetic mix and the technologies that produce this energy. Data requirements, including geographical, technological and time coverage, are applied to the electricity use impact assessment. Other aspects, such as food and drinks, were not locally studied. Information available to convert this consumption into environmental impact units was obtained from studies that consider technologies, production rates and availability of other countries or regions, such as the UK, for the environmental aspect of food and drinks (Defra/DECC, 2014). This means that significant requirements, such as geographical and technological coverage, could not be considered, which limits the interpretation of the assessment results.

Because the university is used as the product system and no differentiation among processes or products of the university is made, according to the ISO definition of allocation no allocation procedure is needed.

\subsubsection{Life Cycle Inventory analysis (LCI)}

Once the product system, the $\mathrm{FU}$ and the SB have been defined, the $\mathrm{LCl}$ is easy to develop. The inventory of environmental aspects was defined considering all of the university's organizational activities. The set of campuses that compose the university can be considered as a small city where people live, eat, move and generate waste. Figure 1 shows the input/output analysis of the university. As inputs, energy and materials are identified, materials are considered in two categories (procurements and food and drinks) with practical purposes. Food and drinks are used and served inside the university but managed by external stakeholders. As they are not purchased by the university itself, the process for considering this aspect is different, which is why this aspect is considered separately. Energy aspects include electricity and fuels. Outputs are separated into waste and waste water. Waste includes recyclable wastes such as paper and cardboard, glass, packaging and organic wastes. Two extra items, mobility and infrastructure, are considered inherent to the university as they are neither inputs nor outputs. Although they are not formal environmental aspects, UPV's EMS identified them as relevant items that require monitoring. Infrastructure can be considered an input (energy and materials), but it is not a yearly input, and its impact is 
considered on an amortized basis due to its life cycle. Mobility is not a regular input or output aspect, but it is a relevant environmental impact that must be considered due to its inherent emissions. The scope of the impact of mobility is restricted to the usage phase of vehicles after considering the followings:

- The usage phase of vehicles represents between the $46 \%$ and $76 \%$ of total energy consumed during its life cycle (Burhham et al, 2006).

- Climate Change category, the most significant for EFA, represents between $67 \%$ and $74 \%$ of GHG emissions (Burnham et al, 2006).

- Private vehicles have multiple uses; they are not used exclusively with academic purposes except for UPV fleet.

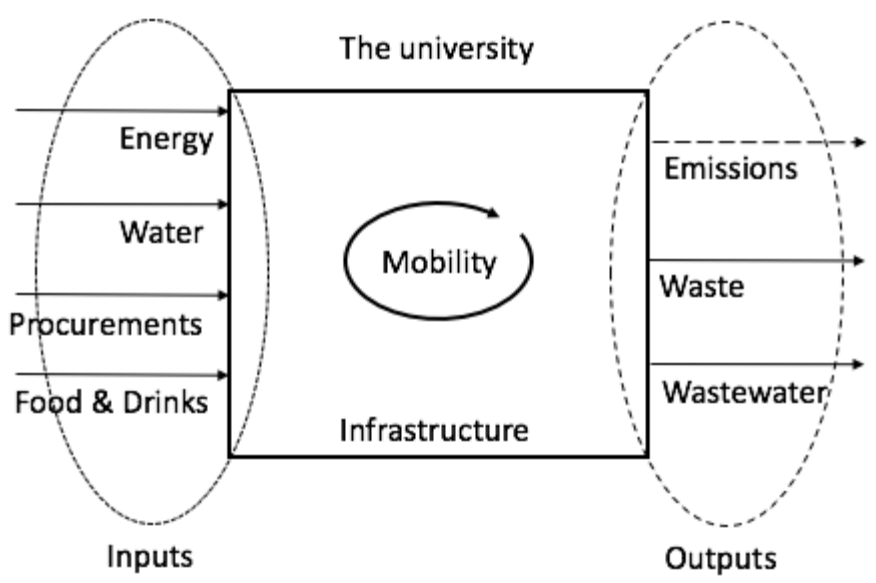

Figure 1. Input/output analysis of the university

In performing this analysis, the following seven environmental aspects were considered:

- Infrastructure

- Food and drinks consumption

- Energy consumption

- Mobility

- Water consumption and treatment

- Procurements/paper consumption

- Waste generation

Emissions were considered in relation of each aspect source.

The EMS verified by UPV'S EMAS already collects data relevant to these aspects. Special attention has been paid to the definition of the aspects to avoid the temptation to skew the study towards available information instead of considering real environmental aspects. However, the difficulty of assessing a decentralized system such as UPV's procurements system made it impossible to evaluate this item properly. To continue with the study, this environmental aspect was simplified to paper 
consumption, which was considered to be a relevant part of the procurement system. Paper purchasing at UPV is centralized. While results may show otherwise, paper is a socially internalized environmental issue at educational institutions.

The difficulty of gathering procurement information biased the $\mathrm{LCl}$ criteria, as other goods such as computers, lab equipment and office equipment were not assessed. A deeper analysis can be performed in further studies to estimate procurement information and consider its life cycle to assign a reasonable environmental impact. When the results are interpreted, the limitations associated with procurement must be considered. This particular point helped the EMS coordination to recognize the need for improvements to include procurement information in the system.

\subsubsection{Life Cycle Impact Assessment (LCIA)}

To assess the environmental impact of each environmental aspect defined in the $\mathrm{LCl}$, conversion factors are needed. As a result of an exhaustive search and analysis, the sources shown in Table 1 were selected for this study.

Table 1. References of conversion factors used in the case study

\begin{tabular}{|c|c|c|}
\hline Environmental aspects & sub-aspects (when needed) & Reference \\
\hline \multicolumn{2}{|c|}{ Food \& Drinks consumption } & Barret et al., 2002 \\
\hline \multirow[t]{4}{*}{ Energy consumption } & Natural Gas & Defra/DECC, 2014 \\
\hline & Gasoil & Defra/DECC, 2014 \\
\hline & Gasoline & Defra/DECC, 2014 \\
\hline & Electricity & $W W F, 2015$ \\
\hline \multirow[t]{4}{*}{ Mobility } & Private transport & Universitat Politècnica de València, 2015 \\
\hline & Public transport & Universitat Politècnica de València, 2015 \\
\hline & UPV's fleet of light vehicles & Universitat Politècnica de València, 2015 \\
\hline & UPV's fleet of heavy vehicles & Universitat Politècnica de València, 2015 \\
\hline \multirow[t]{2}{*}{ Water consumption } & Well water & Marañón et al, 2008 \\
\hline & Main water & Lemos et al, 2013 \\
\hline \multirow[t]{2}{*}{ Paper consumption } & Recycled paper & Hernández Gallego, 2015 \\
\hline & Virgin paper & Hernández Gallego, 2015 \\
\hline \multicolumn{2}{|l|}{ Infrastructure } & Cuchí i Burgos \& López Caballero, 2005 \\
\hline Waste & Paper waste & Marañón et al, 2008 \\
\hline
\end{tabular}




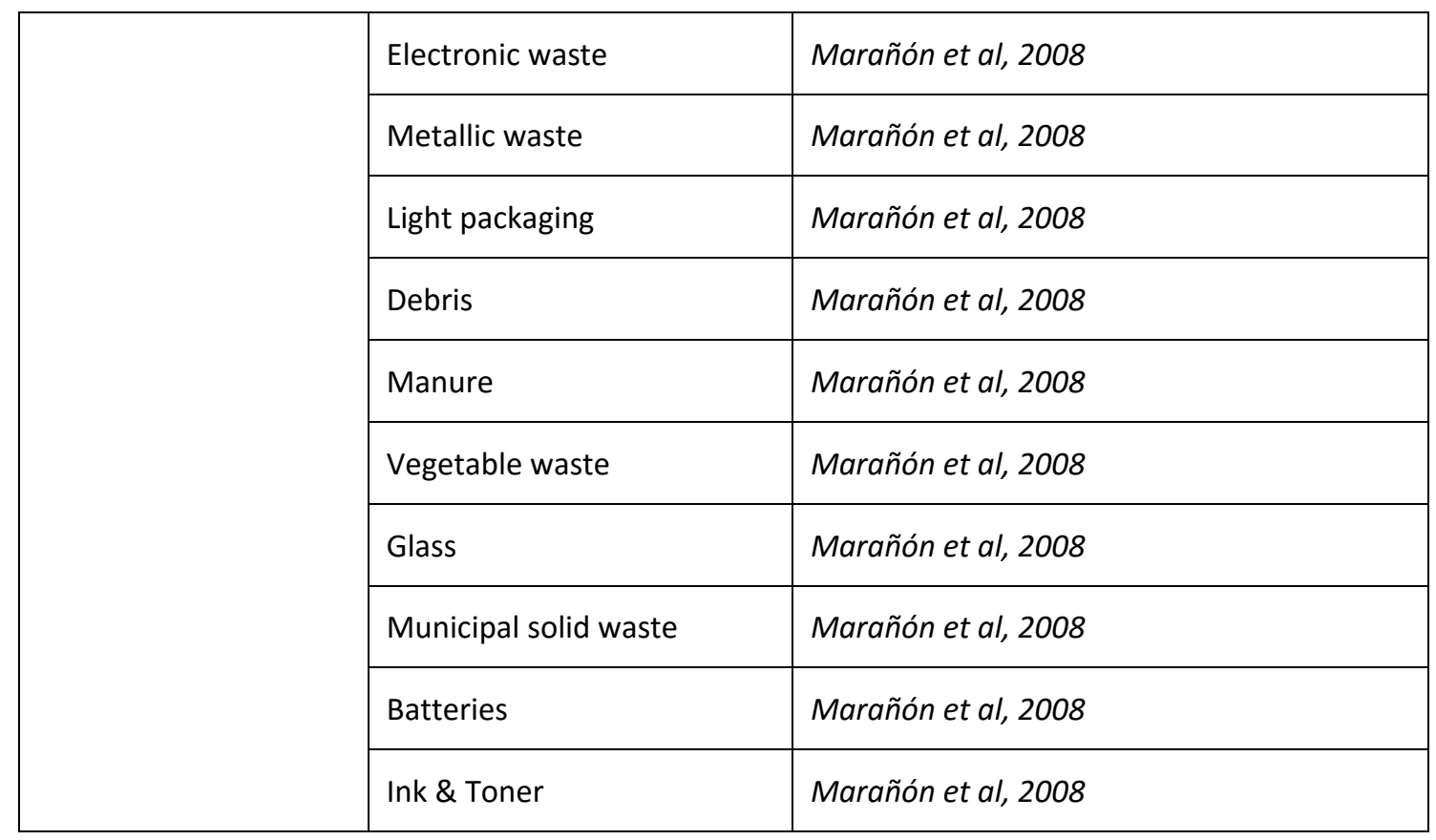

Although not all of the conversion factors meet data requirements, they are the most suitable factors available. All limitations of the assessment due to data requirements such as geographical and technological coverage are considered in the section focused on the interpretation of results.

Despite its difficulties, LCIA methodology and types of impacts were defined by taking $\mathrm{LCl}$ criteria under consideration. In accordance with one of the goals of this study developing an EFA case study - the following two indicators were assessed: carbon footprint and productive footprint. Carbon footprint represents the land - global hectare unit (gha) - required to absorb greenhouse gas (GHG) emissions and represents approximately $85 \%$ of the EFA. The productive footprint is obtained from the land required to produce goods and services and assimilate generated waste. Results obtained for UPV's case study are shown in absolute value (gha) in Figure 2 iError! No se encuentra el origen de la referencia.. The left axis represents the impact of each environmental aspect considered (in \%), while the right axis represents the absolute value in global hectares (gha) for each year studied. Notice that the scale of the right axis is between 0,20 and 0,50 gha/eqst. 


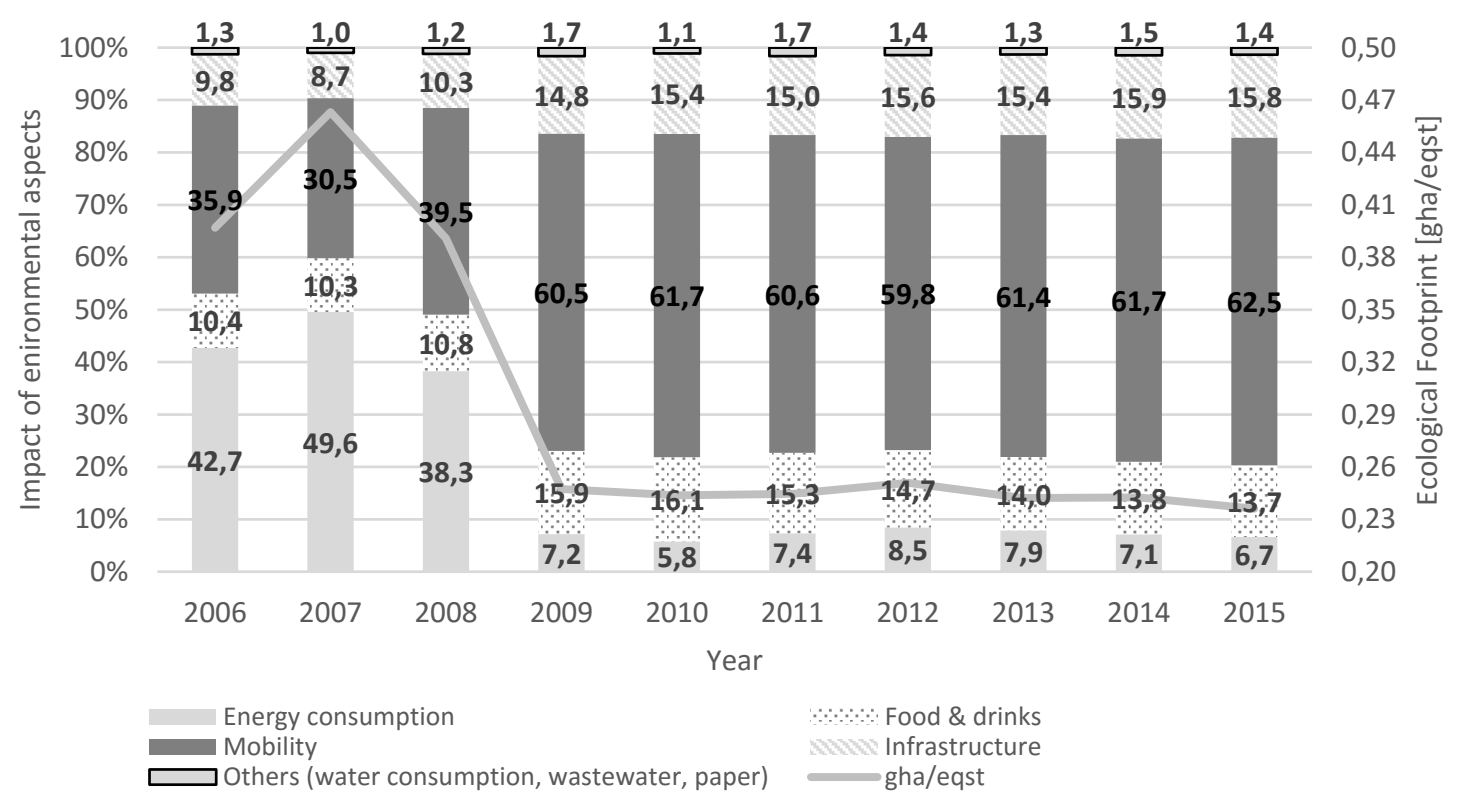

Figure 2. Results of UPV's case study: ecological footprint

\subsubsection{Interpretation of results}

Although the main objective of this study is not to deeply analyze the results of the EFA of UPV (Figure 2), it is important to notice a significant reduction between 2007 and 2009. This is due to a significant net reduction in electricity consumption due to specific actions taken by the staff that operates EMS.

Comparative results for different FUs are presented here for the purposes of evaluating differences. The descriptions of the other FUs are presented below.

- Licenses over results: number of licenses registered over research results. This unit attempts to assess the university's mission of knowledge transfer.

- Journal articles published: number of research articles published in index journals could represent a relevant aspect of the university's research mission.

- $€ R+D+I$ : investment in research, development and innovation activities in euros.

- Enrolled credits: number of total credits in which students are enrolled.

- Equivalent people: the group of people (students, professors and staff) who are part of the university on a full-time basis according to the academic calendar.

To analyze the influence of FUs, Figure 3 shows results for UPV's FUs. The bars and the left axis show the EFA of the university without considering FUs as a representation of the university's organizational performance including all activities needed to achieve its missions. The results of the different FUs are shown on the right axis. 


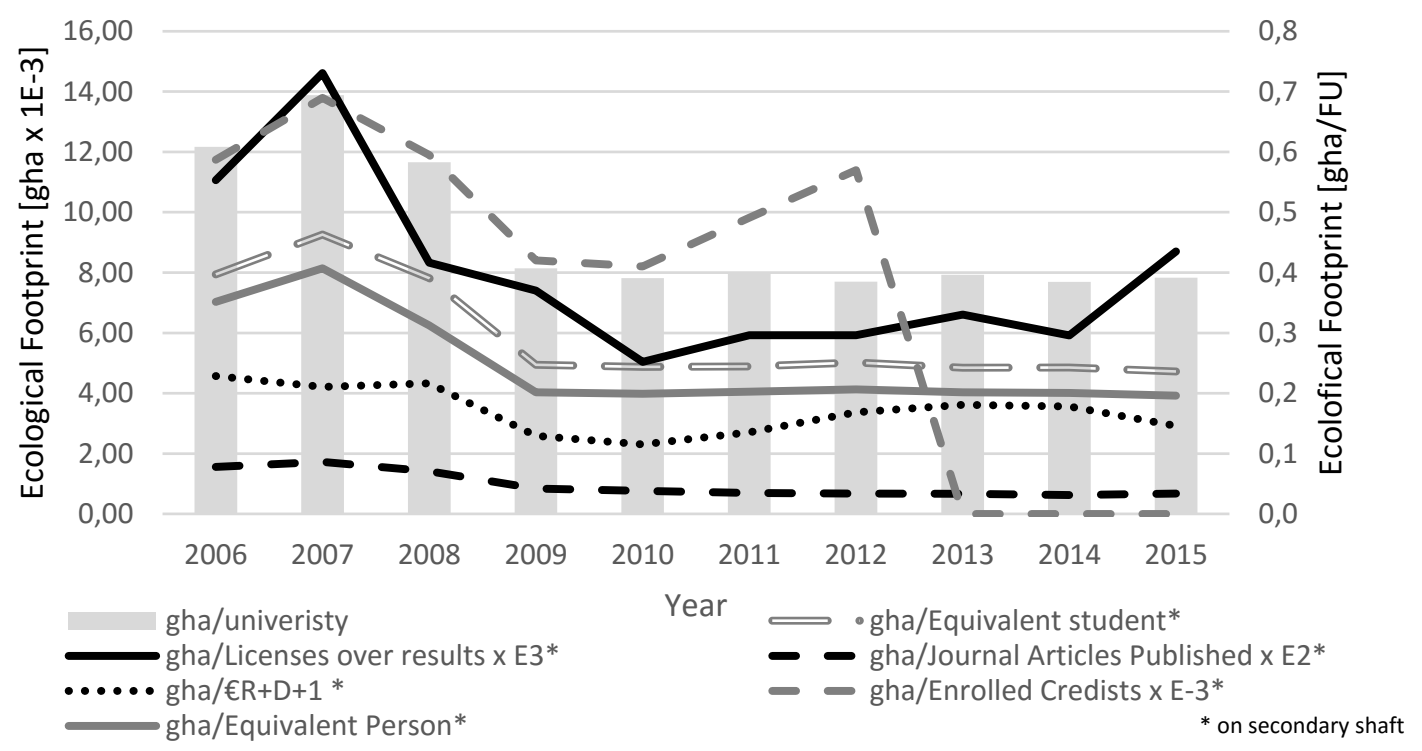

Figure 3. Results of EFA of UPV by FU

Each result shows a different trend depending on the FU. Assuming that the EFA result using the university as a unit without defining an FU represents the real trend of the environmental impact of the university as all aspects - with exceptions (inputs, outputs, mobility and infrastructure) - are assessed, the following interpretations can be made:

- The trend of results using enrolled credits and journal articles published as FUs looks contradictory. When using licenses over results and $€ R+D+I$ as an $F U$, an irregularity is obtained. None of the three results have a strict relationship with what we considered a real trend (in bars).

- These results stress the similarity in the trend of the results in gha (bars) considering the university as a unit and the results considering equivalent students and equivalent people as the FU. The same interpretation is valid when journal articles published is the FU.

The choice of equivalent student as an FU is supported by a similar trend for the clear environmental impact. Equivalent people could also be a valid alternative. Although journal articles published does not seem to have a direct relationship with the teaching mission, it is related to the research and knowledge transfer missions. Due to its similarity with what it is consider as the clear environmental impact, journal articles published is an FU that deserves a deeper analysis in further studies.

In any case, the results of the EFA of UPV can only be considered as an approximation useful to assess tendency and magnitude. The following limitations must be considered:

- Data requirements both for UPV data and for conversion factors are not always adequate, i.e., the geographical coverage for some types of energy 
- The $\mathrm{LCl}$ has not been completely assessed due to the lack of information on procurements

A deeper analysis calculating an estimate can provide a better approach.

The results can also be analyzed by comparing campuses' impacts according to the definition of the SB. As the environmental policy of the university is unique for all campuses, and actions are taken for the university as a whole, it is not considered relevant for this first approach, even though it can be useful in the future to promote more ambitious actions.

\subsection{Step 3. Analyze other studies of the use of EFA by universities}

Developing UPV's case study highlighted both critical decisions defined by ISO and developmental challenges. The experience of developing the UPV case study has been applied in the analysis of other universities' EFA studies. Table 2 summarizes critical decisions for 23 universities all over the world that published their experience with EFA. Figure 3 shows the analysis of the information contained in this table. References for each publication can be found in Table 2. These decisions affect the way the assessment was developed. Therefore, its scope and comparability are conditioned.

Allocation procedures and LCIA methodology and types of impact are analyzed in each assessment. Although allocation procedures are not necessary in cases where the university is the product system, this is not mentioned or justified in most studies. The bibliography is the most commonly used source with which to establish LCIA methodology and types of impacts.

Data and quality requirements and product system identification are also shown in Table 2. The university is considered the product system in most cases, but data and quality requirements are commonly unspecified. The lack of requirement specifications for data and data quality may be driven by a lack of management systems that provide quality information.

Although the reference to LCA has been included in the study, it is not considered a critical decision but rather a statement of how the study was developed. Only $26 \%$ of studies referenced LCA as a tool with which to frame the assessment, while the other $74 \%$ did not make any reference to LCA. An important number of these studies were not designed as scientific research but rather as management and transparency exercises, and it should be noted that only $47.8 \%$ of the sources are journals. Data from two of these studies (8.7\%) are published on institutional websites, while the remaining studies (a 43.5\%) are various publications such as monographs, theses and reports. Although $30.4 \%$ of these studies are published in a language other than English, the information contained in them is considered relevant, and they were included in the study. 
Unfortunately, 'unspecified' is a common value in some of the decisions. The percentage of universities that specified their decision for each item and the percentage of coincidence with the most common approach are used as an indicator of homogeneity or disparity (Figure 3).

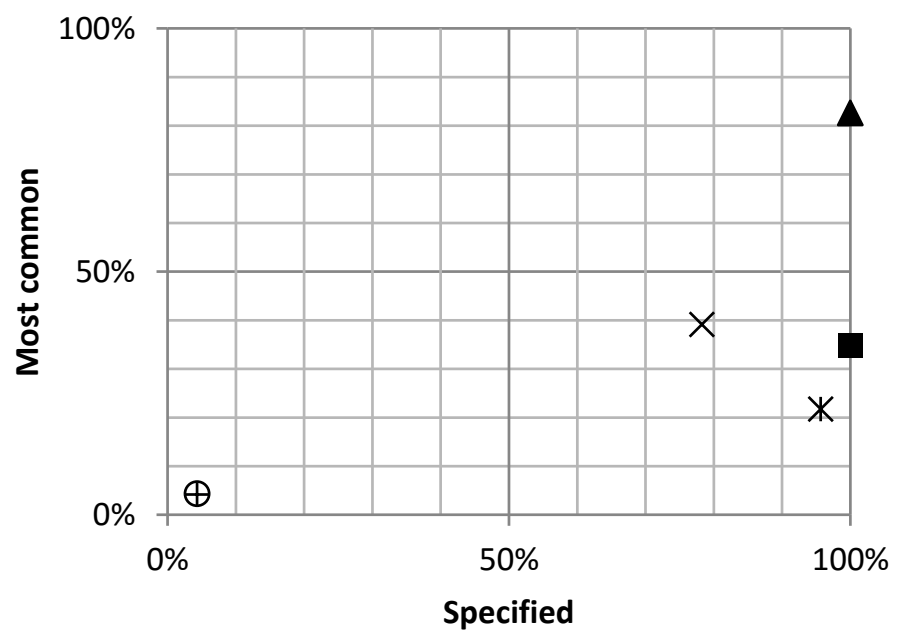

$\Delta$ Product System

$\times$ LCIA methodology and type of impacts

- Functional Unit

* Criteria followed

O Allocation procedures

+ Data and quality

requirements

Note that Allocation Procedure: and quality requirements overli

Figure 3. Statistical analysis of critical decisions in EFA studies

Analyzing Figure 3, critical decisions can be classified into the following three concepts:

- Standardized: a high level of specification and homogeneity considering the definition of the product system.

- Relevant but not standardized: a high level of specification with disparity in the criteria followed for the $\mathrm{LCl}$ definition and in the definitions of the FU and LCIA methodologies.

- Non-standardized: a low level of specification with disparity when considering allocation procedures and the definition of data and quality requirements.

Non-standardized decisions require a deep analysis. Critical decisions in this category were taken under consideration in only 2 of the 23 studies analyzed, and very different choices were made. In most cases, the allocation procedure was not mentioned, and the factors applied to assess each environmental aspect were not justified or - in the best cases - were cited from other studies without considering discrepancies in criteria. Data and quality requirements were often set in terms of availability and not as a previous requirement. In both cases, the same problem of data availability was reflected in the UPV case study.

Data availability is a critical issue. There is a lack of research on conversion factors for EFA. Although research on conversion factors can be performed by universities with a research mission, due to the complexity of the assessment, it does not seem feasible to do this in a short period of time or for internal use only. The data and data quality for making a critical decision can be easily accessed using an EMS. The case study at UPV was developed with high quality data thanks to the EMS that was verified by 
EMAS, notwithstanding the exceptions mentioned. The time to implement and adjust the EMS has to be taken into consideration.

Data and quality requirements have a direct impact on LCIA methodology, $\mathrm{LCl}$ definitions and the criteria followed; these three critical decisions were highly specified but had a low degree of homogeneity.

The complete analysis of environmental aspects is shown in Figure 4.

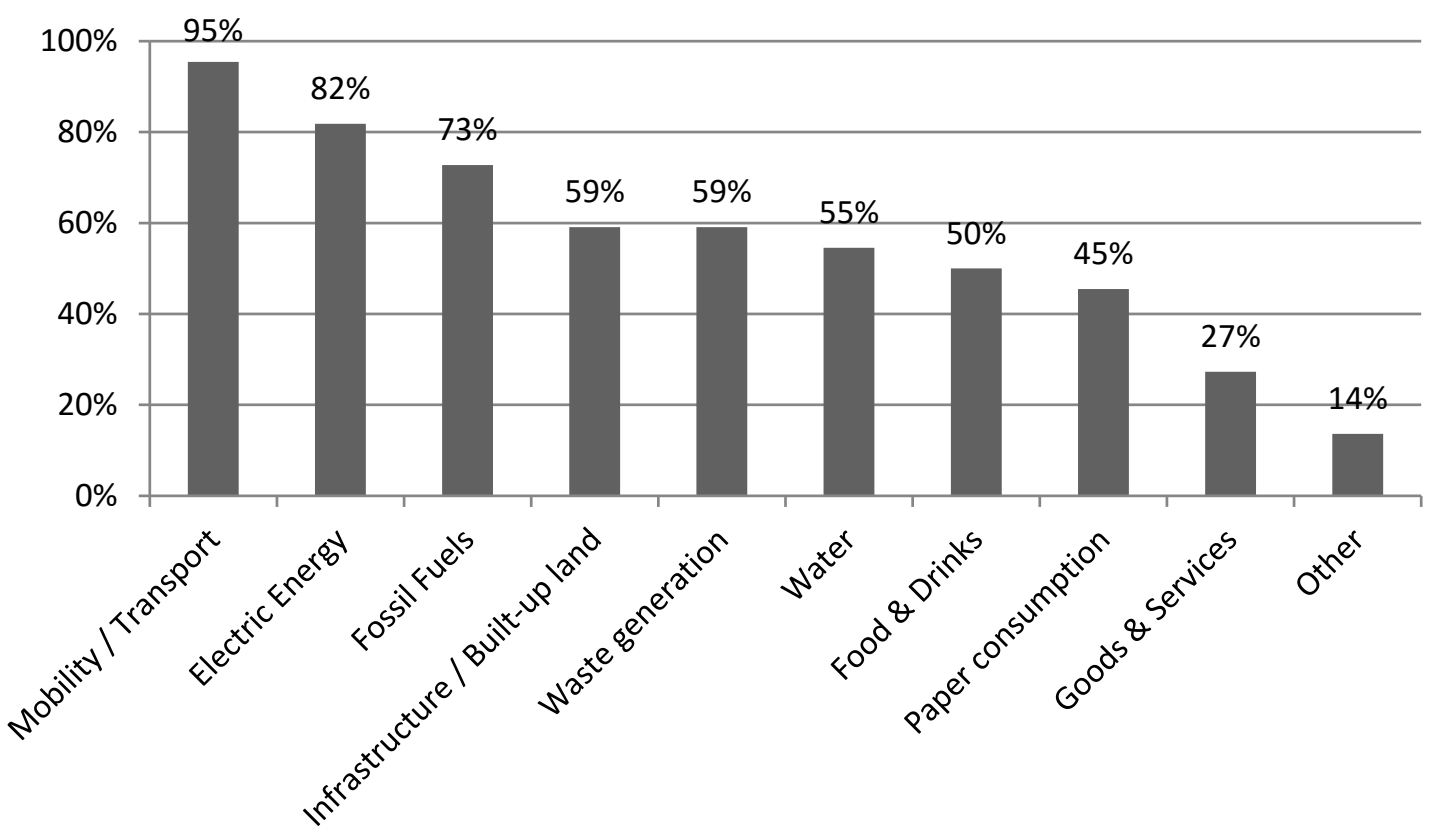

Figure 4. Percentage of studies that considered each environmental aspect

Some environmental aspects are commonly considered in almost all studies; mobility, electric and fossil fuel consumption, infrastructure, food and drinks and waste generation were considered in over $50 \%$ of the studies. Goods and services were considered in $\mathbf{2 7 \%}$ of studies, and this diverse aspect includes both hazardous materials and office equipment. Only one study considered equipment, but it did not specify how was considered. Environmental aspects that are particular to a study - i.e., degraded land at Holme Lancy College (Dawe et al., 2004) - are classified as 'other'. The university and the campus were considered as options for the definition of the product system. A thorough study has to be made to ensure that there is a significant difference between these two options. A campus may be understood as a physical barrier over the land that the organization owns, while a university might consider not only the land they own but also the territory affected by its activities.

\section{CONCLUSIONS}

Using a methodology based on LCA has proven to be adequate for detecting critical points and specific drawbacks of EFA as used by universities. UPV's case study was 
useful for understanding the application of the LCA concept and defining the framework in which to study the use of EFA by universities.

These results show that there are some important methodological deficiencies that make it difficult to compare studies among campuses and standardize EFA methodology. Some important elements that affect the final outcome, such as data and quality requirements, are inadequate in most cases. In addition, the LCIA methodology or the criteria for the $\mathrm{LCl}$ definition is based on data availability, and in most cases, it is not further justified. The analysis of the use of EFA by universities demonstrates the difficulty of gathering information in cases where no EMS operates. Interviewing the developers of each study is essential for performing a deeper analysis of the decisions made when developing their EFA.

There is an inherent difficulty in defining the function of a university that goes beyond the domain of LCA or any other tool. Thus, universities are one of the most complex organizations to define in these terms. Any simplistic approach that limits a university to only lecturing, research, technology transfer or other missions may provide a valid unit in terms of purposed equivalent student units, but it will ultimately be incomplete. It is important to consider all functions - also sometimes called missions - as stated in the introduction of this article. Defining the function of a university is vital to unambiguously establish the FUs and SB and to define the framework of the assessment. Comparability without well-defined FUs and SB is not possible.

Although some authors believe that EFA has the potential to become a good indicator of environmental performance with which to promote ecological sustainability, the results of this study show that universities follow diverse approaches, which does not allow for comparison of criteria, scope or essence. However, the EFA methodology can be improved with LCA principles.

Future studies may define a taxonomy that ensures that different assessments can be rendered comparable. Although foundations that have proved useful for LCA seem to be appropriate for EFA, this field still needs considerable research. The assessment of OLCA for Universitat Politècnica de València according to ISO 14072:2015 could provide relevant information and knowledge with which to define a standard methodology for EFA.

Regarding the case study, different estimations can be applied; a better assessment of procurement environmental aspect is pending. A deeper analysis comparing impacts by campuses can also be made.

\section{ACKNOWLEDGMENTS}

The authors would like to thank the Universitat Politècnica de València and especially the Environmental Office for its help in gathering and making available the environmental information needed to perform this study. 


\section{REFERENCES}

Alonso-Almeida, M.d.M., Marimon, F., Casani, F., \& Rodriguez-Pomeda, J. (2015). Diffusion of sustainability reporting in universities: Current situation and future perspectives. Journal of Cleaner Production, 106, 144-154. doi:10.1016/j.jclepro.2014.02.008

Alshuwaikhat, H. M., \& Abubakar, I. (2008). An integrated approach to achieving campus sustainability: Assessment of the current campus environmental management practices. Journal of Cleaner Production, 16(16), 1777-1785. doi:10.1016/j.jclepro.2007.12.002

Álvares, N. L., \& Rodriguez, R. L. (2007). Estimación da pegada ecolóxica en dous centros da universidade de santiago de compostela. Posibles implicacións educativas. Ambientalmente sustentable. 99-117.

Arroyo, P. (2009). Ecological footprint of the campus de Vegazana, León university; a calculation approach. Implications for the sustainability of the university community. MAPFRE, 1-20.

Azqueta, D., \& Delacamara, G. (2006). Ethics, economics and environmental management. Ecological Economics, 56(4), 524-533.

doi:10.1016/j.ecolecon.2005.03.003

Barrett, J., Vallack, H., Jones, A., and Haq, G. (2002). A material flow analysis and ecological footprint of York. Stockholm, 129. Retrieved June 15, 2013 from: http://seiinternational.org/mediamanager/documents/Publications/Future/Material Flow Analysis york.pdf/npapers2://publication/uuid/9F1C847A-09B8-47F5-BAF8892555E87ACE

Brundtland Commision. (1987). Report of the world commission on environment and development: Our common future UN General Assembly Resolution A/RES/42/187.

Burgess, B., \& Lai, J. (2006). How much land is used by Kwantlen University College? Retrieved June 15, 2013 from: http://www.kpu.ca/ shared/assets/KUC Ecological Footprint Report2114.pdf

Burnham, A., Wang, M., Wu, Y. (2006) Development and applications of GREET 2.7-The transportation vehicle-cycle model. Argonne: Argonne National Laboratory (ANL), U.S. Department of Energy. doi:10.2172/898530.

Castellani, V., \& Sala, S. (2012). Ecological footprint and life cycle assessment in the sustainability assessment of tourism activities. Ecological Indicators, 16, 135-147. doi:10.1016/j.ecolind.2011.08.002

Cuchí i Burgos, A., \& López Cabeallero, I. (2005) Informe MIES: Una proximació a I'impacte ambiental de l'Escola d'Artquitectura del Vallès. Universitat Politècnica de Catalunya. ISBN: 84-7653-870-7 
Ceulemans, K., Lozano, R., and Alonso-Almeida, M. (2015). Sustainability Reporting in Higher Education: Interconnecting the Reporting Process and Organizational Change Management for Sustainability. Sustainability 7, 8881-8903. doi:10.3390/su7078881

Clarke, A., \& Kouri, R. (2009). Choosing an appropriate university or college environmental management system. Journal of Cleaner Production, 17(11), 971984. doi:10.1016/j.jclepro.2009.02.019

Conway, T. M., Dalton, C., Loo, J., \& Benakoun, L. (2008). Developing ecological footprint scenarios on university campuses: A case study of the University of Toronto at Mississauga. International Journal of Sustainability in Higher Education, 9(1), 4-20. doi: 10.1108/14676370810842157

Dawe, G. F. M., Vetter, A., \& Martin, S. (2004). An overview of ecological footprint and other tools and their application to the development of sustainability process: Audit and methodology at Holme Lacy College, UK. International Journal of Sustainability in Higher Education, 5(4), 340-371. doi: 10.1108/14676370410561063

de Miguel, J. J. (2012). Emisiones de CO2 en la EUP. Escuela Politécnica Universitaria de Valladolid. Retrieved June 15, 2013 from http://www.eup.uva.es/emisionesco2/.

Defra/DECC (2014). Government conversion factors for company reporting Retrieved June 15, 2013 from http://www.ukconversionfactorscarbonsmart.co.uk/.

Denman, B. D. (2009). What is a university in the 21st century? Higher Education Management and Policy, 17(2), 9-28. doi: 10.1787/17269822

Disterheft, A., Ferreira da Silva Caeiro, S. S., Ramos, M. R., \& de Miranda Azeiteiro, U. M. (2012). Environmental management systems (EMS) implementation processes and practices in European higher education institutions-Top-down versus participatory approaches. Journal of Cleaner Production, 31, 80-90. doi:10.1016/j.jclepro.2012.02.034

Escuela Politécnica Universitaria de Valladolid. (2009). Emisiones CO2. Retrieved June 15, 2013, from www.eup.uva.es/emisionesco2

Finkbeiner, M. (2009). Carbon Footprinting. Opportunities and threats. International Journal of Life Cycle Assessment, (14), 91-94. doi: 10.1007/s11367-009-0064-x

Finkbeiner, M., Ackermann, R., Bach, V., Berger, M., Brankatschk, G., Chang, Y.-J., Grinberg, M., Lehmann, A., Martínez-Blanco, J., Minkov, N. (2014). Background and Future Prospects in Life Cycle Assessment. In Background and Future Prospects in Life Cycle Assessment, W. Klöpffer, 207. doi:10.1007/978-94-0178697-3

Flint, K. (2001). Institutional ecological footprint analysis. A case study of the University of Newcastle, Australia. International Journal of Sustainability in Higher Education, 2(1), 48-62. doi: 10.1108/1467630110380299

Galli, A., Kitzes, J., Niccolucci, V., Wackernagel, M., Wada, Y., \& Marchettini, N. (2012). Assessing the global environmental consequences of economic growth through 
the ecological footprint: A focus on china and India. Ecological Indicators, 17, 99107. doi:10.1016/j.ecolind.2011.04.022

Giménez, A., Pérez, I., Montesions, P., Vera, V., \& Bordonado, S. (2009). Transporte y sostenibilidad. Pautas de movilidad y alternativas de reducción de la huella ecológica en centros de trabajo. La universidad Miguel Hernández como caso de estudio. Seguridad y Medio Ambiente, 40-51.

Hernández Gallego; E.; Cano Herrador; C.; Correoa Guimaraes; A. (2015) La Huella Ecológica de la Universidad de; 2016 from http://www.uva.es/export/sites/uva/7.com

Hertwich, E. G. (2005). Life cycle approaches to sustainable consumption: A critical review. Environmental Science \& Technology, 39(13), 4673-4684. doi: 10.1021/es0497375

Herva, M., Franco, A., Carrasco, E. F., \& Roca, E. (2011). Review of corporate environmental indicators. Journal of Cleaner Production, 19(15), 1687-1699. doi:10.1016/j.jclepro.2011.05.019

Herva, M., Hernando, R., Carrasco, E. F., \& Roca, E. (2010). Development of a methodology to assess the footprint of wastes. Journal of Hazardous Materials, 180(1), 264-273. doi:10.1016/j.jhazmat.2010.04.026

Herva, M., Franco, A., Ferreiro, S., Alvarez, A., \& Roca, E. (2008). An approach for the application of the ecological footprint as environmental indicator in the textile sector. Journal of Hazardous Materials, 156(1-3), 478-487.

doi:10.1016/j.jhazmat.2007.12.077

International Organization for Standardization (2006a). Environmental management life cycle assessment - principles and framework. ISO 14040:2006.

International Organization for Standardization (2006b). Environmental management life cycle assessment - requirements and guidelines. ISO 14044:2006(E),

Janis, J. (2007). Quantifying the ecological footprint of the ohio state university The Ohio State University. Retrieved June 15, 2013 from http://hdl.handle.net/1811/28365

Jorge, J., \& Busquets, P. (2000). La petjada ecologica de l'EUPM. Universitat Politecnica de Catalunya. Retrieved June 15, 2013 from www.upc.edu/mediambient

Joseph, G. (2012). Ambiguous but tethered: An accounting basis for sustainability reporting. Critical Perspectives on Accounting, 23(2), 93-106. doi:10.1016/j.cpa.2011.11.011

Klassen, R. D., \& McLaughlin, C. P. (1996). The impact of environmental management on firm performance. Management Science, 42(8), 1199-1214. doi: $0.1287 /$ mnsc.42.8.1199

Klein-Banai, C., \& Theis, T. L. (2011). An urban university's ecological footprint and the effect of climate change. Ecological Indicators, 11(3), 857-860.

doi:10.1016/j.ecolind.2010.11.002 
Lambrechts, W., \& Van Liedekerke, L. (2014). Using ecological footprint analysis in higher education: Campus operations, policy development and educational purposes. Ecological Indicators, 45, 402-406. doi:10.1016/j.ecolind.2014.04.043

Lemos, D., Dias, A., Gararrell, X. \& Arroja, L. (2013) Environmental assessment of an urban water system. Journal of Cleaner Production, 54, 157-165. doi: 10.1016/j.jclepro.2013.04.029

Lenzen, M., Lundie, S., Bransgrove, G., Charet, L., \& Sack, R. (2002). A novel ecological footprint and an example application. ISA Research Paper, 02-02.

Letete, T. C., Mungwe, N. W., Guma, M., \& Marquard, A. (2011). Carbon footprint of the University of Cape Town. Journal of Energy in Southern Africa, 22(2), 2-12.

Li, G., Wang, Q., Gu, X., Liu, J., Ding, Y., \& Liang, G. (2008). Application of the componential method for ecological footprint calculation of a Chinese university campus. Ecological Indicators, 8(1), 75-78. doi:10.1016/j.ecolind.2007.01.007

Lozano, R. (2006). Incorporation and institutionalization of SD into universities: Breaking through barriers to change. Journal of Cleaner Production, 14(9), 787796. doi:10.1016/j.jclepro.2005.12.010

Lozano, R., Lozano, F. J., Mulder, K., Huisingh, D., \& Waas, T. (2013). Advancing higher education for sustainable development: International insights and critical reflections. Journal of Cleaner Production, 48, 3-9.

doi:10.1016/j.jclepro.2013.03.034

Lozano, R., Ceulemans, K., Alonso-Almeida, M., Huisingh, D., Lozano, F. J., Waas, T., Lambrechts, W., Lukman, R., and Hugé, J. (2015). A review of commitment and implementation of sustainable development in higher education: results from a worldwide survey. Journal of Cleaner Production, 108, 1-18. doi:10.1016/j.jclepro.2014.09.048

Marañón, E., Iregui, G., Doménech, J.L., Fernández-Nava, Y. \& González, M. (2008). Propuesta de índices de conversion para la obtención de la huella de los residuos y vertidos. Observatorio Iberoamericano del Desarrollo Local y la Economía Social, 4. ISSN: 1988-2483.

Martínez-Blanco, J., Inaba, A., Quiros, A., Valdivia, S., Milà-i-Canals, L., and Finkbeiner, M. (2015). Organizational LCA: the new member of the LCA family-introducing the UNEP/SETAC Life Cycle Initiative guidance document. The International Journal of Life Cycle Assessment, 10-12. doi: 10.1007/s11367-015-0912-9

Nunes, L., Catarino, A., Teixeira, M. R., \& Cuesta, E. (2013). Framework for the intercomparison of ecological footprint of universities. Ecological Indicators, 32, 276284. doi:10.1016/j.ecolind.2013.04.007

Olalla-Tárraga, M. A. (2003). Indicadores de sostenibilidad y huella ecológica aplicada a la UAM.

Paulson, K. (1997). The transport footprint of Oxford Brookes University. Oxford Brookes University. 
Rees, W., \& Wackernagel, M. (1996). Urban ecological footprints: Why cities cannot be sustainable - and why they are a key to sustainability. Environmental Impact Assessment Review, 16(4-6), 223-248.

Roseland, M. (2000). Sustainable community development: Integrating environmental, economic, and social objectives. Progress in Planning, 54(2), 73-132. doi:10.1016/S0305-9006(00)00003-9

Seiffert, M. E. B., \& Loch, C. (2005). Systemic thinking in environmental management: Support for sustainable development. Journal of Cleaner Production, 13(12), 11971202. doi:10.1016/j.jclepro.2004.07.004

Soto, M., \& Pérez, M. (2010). A pegada ecolóxica da Universidade da Coruña Vicerrectoría da Infraesttuturas e Xerstión Ambiental - Universidade da Coruña.

Torregrosa-López, J. I., Lo lacono-Ferreira, V. G., Barranco-Martí, C., \& Bellver-Navarro, C. G. (2016). The strengths of EMAS as an environmental management system for European university campuses. International Journal of Environment and Sustainable Development, Vol. 15, No.1, 89-106. doi: http://dx.doi.org/10.1504/IJESD.2016.073339

UNEP. (1992). Rio declaration on environment and development. United Nations Environment Program (UNEP). Retrieved September 15, 2015 from http://www.unep.org/Documents.Multilingual/Default.asp?documentid=78\&articl eid=1163

UNEP (2015) Guidance on Organizational Life Cycle Assessment. Life-Cycle Initiative, United Nations Environment Program and Society for Environmental Toxicology and Chemistry, Paris, France, http://www.lifecycleinitiative.org/wpcontent/uploads/2015/04/o-Ica_24.4.15-web.pdf

Universitat de Girona (2013). Petjada ecològica de la UdG - càlcul de la petjada ecològica derivada dels consums energètics dels edificis universitaris, 1999 - 2008. Retrieved June 15, 2013 from http://www3.udg.edu/ov/recursos/petjada.htm

Universitat Politècnica de València (2015). Plan de movilidad sostenible. Diagnóstico de situación inicial. Unidad de Medio Ambiente. Retrived January 2, 2015 from https://www.upv.es/entidades/AMAPUOC/infoweb/ov/info/887195normalc.html

Venetoulis, J. (2001). Assessing the ecological impact of a University. The ecological footprint for the University of Redlands. International Journal of Sustainability in Higher Education, 180-196. doi: 10.1108/14676370110388381

Viebahn, P. (2002). An environmental management model for universities: From environmental guidelines to staff involvement. Journal of Cleaner Production, 10(1), 3-12. doi:10.1016/S0959-6526(01)00017-8

Viñoles-Cebolla, R., Bastante-Ceca, M., Capuz-Rizo, S. F. (2015) An integrated method to calculate an automobile's emissions throughout its life cycle. Energy, 83, 125136. doi:10.1016/j.energy.2015.02.006

Wackernagel, M., \& Rees, W. E. (1997). Perceptual and structural barriers to investing in natural capital: Economics from an ecological footprint perspective. Ecological Economics, 20(1), 3-24. doi:10.1016/S0921-8009(96)00077-8 
Wiedmann, T., \& Barrett, J. (2010). A review of the ecological footprint indicatorperceptions and methods. Sustainability, 2(6), 1645-1693. doi:10.3390/su2061645

Willamette University Sustainability Council. (2008). 2007-2008 sustainability indicators report. Willamette Wniversity

Wright, E., Gill, B., Wallin, P., Hutchison, K., \& Prebble, M. (2009). The ecological footprint of UEA.

Wright, E. P., \& Drossman, H. (2002). The ecological footprint of the Colorado College: An examination of sustainability. Environmental Science, 5(1), 23

WWF. (2015.). Observatorio de la electricidad. Retrieved June 15, 2013 from http://www.wwf.es/que hacemos/cambio climatico/nuestras soluciones/energia s renovables/observatorio de la electricidad/ 


\section{Appendix}

Table 2. Critical decisions of EFA studies

\begin{tabular}{|c|c|c|c|c|c|c|c|}
\hline University & $\begin{array}{l}\text { Referen } \\
\text { ce to } \\
\text { LCA }\end{array}$ & $\begin{array}{l}\text { Functional } \\
\text { unit }\end{array}$ & $\begin{array}{l}\text { Allocation } \\
\text { procedures }\end{array}$ & $\begin{array}{l}\text { LCIA } \\
\text { methodology } \\
\text { and types of } \\
\text { impacts }\end{array}$ & $\begin{array}{l}\text { Data and } \\
\text { quality } \\
\text { requirements }\end{array}$ & $\begin{array}{l}\text { Product } \\
\text { system }\end{array}$ & Reference \\
\hline $\begin{array}{l}\text { Colorado } \\
\text { College }\end{array}$ & Yes & $\begin{array}{l}\text { Person who } \\
\text { is part of the } \\
\text { university }\end{array}$ & Unspecified & Unspecified & Unspecified & University & $\begin{array}{l}\text { (E. P. } \\
\text { Wright \& } \\
\text { Drossman, } \\
\text { 2002) }\end{array}$ \\
\hline $\begin{array}{l}\text { East Anglia } \\
\text { University }\end{array}$ & No & $\begin{array}{l}\text { The } \\
\text { university }\end{array}$ & Unspecified & $\begin{array}{l}\text { Bibliography \& } \\
\text { specialized } \\
\text { institutions }\end{array}$ & Unspecified & University & $\begin{array}{l}\text { (E. Wright, } \\
\text { Gill, } \\
\text { Wallin, } \\
\text { Hutchison, } \\
\text { \& Prebble, } \\
\text { 2009) }\end{array}$ \\
\hline $\begin{array}{l}\text { Escuela } \\
\text { Universitar } \\
\text { ia } \\
\text { Politécnica } \\
\text { de } \\
\text { Manresa - } \\
\text { Universitat } \\
\text { Politècnica } \\
\text { de } \\
\text { Catalunya }\end{array}$ & Yes & $\begin{array}{l}\text { Graduated } \\
\text { students }\end{array}$ & Unspecified & $\begin{array}{l}\text { Specialized } \\
\text { institutions }\end{array}$ & Unspecified & School & $\begin{array}{l}\text { (Jorge \& } \\
\text { Busquets, } \\
2000)\end{array}$ \\
\hline $\begin{array}{l}\text { Escuela } \\
\text { Universitar } \\
\text { ia } \\
\text { Politécnica } \\
\text { de } \\
\text { Valladolid } \\
\text { - } \\
\text { Universida } \\
\text { d de } \\
\text { Valladolid }\end{array}$ & Yes & $\begin{array}{l}\text { The } \\
\text { university }\end{array}$ & Unspecified & $\begin{array}{l}\text { Bibliography \& } \\
\text { specialized } \\
\text { institutions }\end{array}$ & Unspecified & School & $\begin{array}{l}\text { (de } \\
\text { Miguel, } \\
\text { 2012) }\end{array}$ \\
\hline $\begin{array}{l}\text { Kwantlen } \\
\text { University } \\
\text { College }\end{array}$ & No & $\begin{array}{l}\text { Person who } \\
\text { is part of the } \\
\text { university }\end{array}$ & Unspecified & Bibliography & Unspecified & University & $\begin{array}{l}\text { (Burgess \& } \\
\text { Lai, 2006) }\end{array}$ \\
\hline $\begin{array}{l}\text { Leuven } \\
\text { University } \\
\text { College }\end{array}$ & No & $\begin{array}{l}\text { The } \\
\text { university }\end{array}$ & Unspecified & Bibliography & Unspecified & University & $\begin{array}{l}\text { (Lambrech } \\
\text { ts \& Van } \\
\text { Liedekerke } \\
\text {, 2014) }\end{array}$ \\
\hline $\begin{array}{l}\text { Northeast } \\
\text { ern } \\
\text { University }\end{array}$ & Yes & $\begin{array}{l}\text { The } \\
\text { university }\end{array}$ & Unspecified & Unspecified & Unspecified & University & $\begin{array}{l}\text { (Li et al., } \\
2008 \text { ) }\end{array}$ \\
\hline $\begin{array}{l}\text { Ohio State } \\
\text { University }\end{array}$ & No & $\begin{array}{l}\text { Person who } \\
\text { is part of the } \\
\text { university }\end{array}$ & Unspecified & $\begin{array}{l}\text { Bibliography \& } \\
\text { specialized } \\
\text { institutions }\end{array}$ & Unspecified & University & $\begin{array}{l}\text { (Janis, } \\
\text { 2007) }\end{array}$ \\
\hline
\end{tabular}




\begin{tabular}{|c|c|c|c|c|c|c|c|}
\hline University & $\begin{array}{c}\text { Referen } \\
\text { ce to } \\
\text { LCA }\end{array}$ & $\begin{array}{c}\text { Functional } \\
\text { unit }\end{array}$ & $\begin{array}{l}\text { Allocation } \\
\text { procedures }\end{array}$ & $\begin{array}{l}\text { LCIA } \\
\text { methodology } \\
\text { and types of } \\
\text { impacts }\end{array}$ & $\begin{array}{c}\text { Data and } \\
\text { quality } \\
\text { requirements }\end{array}$ & $\begin{array}{l}\text { Product } \\
\text { system }\end{array}$ & Reference \\
\hline $\begin{array}{l}\text { Oxford } \\
\text { Brookes } \\
\text { University }\end{array}$ & No & $\begin{array}{l}\text { Person who } \\
\text { is part of the } \\
\text { university }\end{array}$ & Unspecified & Bibliography & Unspecified & University & $\begin{array}{l}\text { (Paulson, } \\
1997)\end{array}$ \\
\hline $\begin{array}{l}\text { Redlands } \\
\text { University }\end{array}$ & No & $\begin{array}{l}\text { The } \\
\text { university }\end{array}$ & Unspecified & Research & Unspecified & University & $\begin{array}{l}\text { (Venetouli } \\
\text { s, 2001) }\end{array}$ \\
\hline $\begin{array}{l}\text { School of } \\
\text { Physics - } \\
\text { Sydney } \\
\text { University }\end{array}$ & Yes & $\begin{array}{l}\text { Person who } \\
\text { is part of the } \\
\text { university }\end{array}$ & Unspecified & Unspecified & Unspecified & School & $\begin{array}{l}\text { (Lenzen, } \\
\text { Lundie, } \\
\text { Bransgrov } \\
\text { e, Charet, } \\
\text { \& Sack, } \\
\text { 2002) } \\
\end{array}$ \\
\hline $\begin{array}{l}\text { Universida } \\
\text { d } \\
\text { Autónoma } \\
\text { de Madrid }\end{array}$ & No & $\begin{array}{l}\text { Person who } \\
\text { is part of the } \\
\text { university }\end{array}$ & Unspecified & Unspecified & Unspecified & University & $\begin{array}{l}\text { (Olalla- } \\
\text { Tárraga, } \\
\text { 2003) }\end{array}$ \\
\hline $\begin{array}{l}\text { Universida } \\
\text { d de } \\
\text { Girona }\end{array}$ & No & $\begin{array}{l}\text { The } \\
\text { university }\end{array}$ & Unspecified & Unspecified & Unspecified & University & $\begin{array}{l}\text { (Universita } \\
\text { t de } \\
\text { Girona,) }\end{array}$ \\
\hline $\begin{array}{l}\text { Universida } \\
\text { d de León }\end{array}$ & No & $\begin{array}{l}\text { Person who } \\
\text { is part of the } \\
\text { university }\end{array}$ & Unspecified & $\begin{array}{l}\text { Bibliography \& } \\
\text { specialized } \\
\text { institutions }\end{array}$ & $\begin{array}{l}\text { Data } \\
\text { availability }\end{array}$ & Campus & $\begin{array}{l}\text { (Arroyo, } \\
\text { 2009) }\end{array}$ \\
\hline $\begin{array}{l}\text { Universida } \\
\text { d de } \\
\text { Santiago } \\
\text { de } \\
\text { Compostel } \\
\text { a }\end{array}$ & No & $\begin{array}{l}\text { Person who } \\
\text { is part of the } \\
\text { university }\end{array}$ & Unspecified & $\begin{array}{l}\text { Bibliography \& } \\
\text { specialized } \\
\text { institutions }\end{array}$ & Unspecified & University & $\begin{array}{l}\text { (Álvares \& } \\
\text { Rodriguez, } \\
2007 \text { ) }\end{array}$ \\
\hline $\begin{array}{l}\text { Universida } \\
\text { d Miguel } \\
\text { Hernández }\end{array}$ & No & $\begin{array}{l}\text { Person who } \\
\text { is part of the } \\
\text { university }\end{array}$ & Unspecified & $\begin{array}{l}\text { Bibliography \& } \\
\text { specialized } \\
\text { institutions }\end{array}$ & Unspecified & University & $\begin{array}{l}\text { (Giménez, } \\
\text { Pérez, } \\
\text { Montesion } \\
\text { s, Vera, \& } \\
\text { Bordonad } \\
\text { o, 2009) }\end{array}$ \\
\hline $\begin{array}{l}\text { Universida } \\
\text { de da } \\
\text { Coruña }\end{array}$ & No & $\begin{array}{l}\text { Person who } \\
\text { is part of the } \\
\text { university }\end{array}$ & $\begin{array}{l}\text { By collective or } \\
\text { campus }\end{array}$ & $\begin{array}{l}\text { Bibliography \& } \\
\text { specialized } \\
\text { institutions }\end{array}$ & Unspecified & University & $\begin{array}{l}\text { (Soto \& } \\
\text { Pérez, } \\
\text { 2010) }\end{array}$ \\
\hline $\begin{array}{l}\text { University } \\
\text { of Cape } \\
\text { Town }\end{array}$ & No & $\begin{array}{l}\text { The } \\
\text { university }\end{array}$ & Unspecified & $\begin{array}{l}\text { Bibliography \& } \\
\text { specialized } \\
\text { institutions }\end{array}$ & Unspecified & University & $\begin{array}{l}\text { (Letete, } \\
\text { Mungwe, } \\
\text { Guma, \& } \\
\text { Marquard, } \\
\text { 2011) }\end{array}$ \\
\hline
\end{tabular}




\begin{tabular}{|c|c|c|c|c|c|c|c|}
\hline University & $\begin{array}{l}\text { Referen } \\
\text { ce to } \\
\text { LCA }\end{array}$ & $\begin{array}{c}\text { Functional } \\
\text { unit }\end{array}$ & $\begin{array}{l}\text { Allocation } \\
\text { procedures }\end{array}$ & $\begin{array}{l}\text { LCIA } \\
\text { methodology } \\
\text { and types of } \\
\text { impacts }\end{array}$ & $\begin{array}{c}\text { Data and } \\
\text { quality } \\
\text { requirements }\end{array}$ & $\begin{array}{l}\text { Product } \\
\text { system }\end{array}$ & Reference \\
\hline $\begin{array}{l}\text { University } \\
\text { of Holme }\end{array}$ & Yes & $\begin{array}{l}\text { Person who } \\
\text { is part of the } \\
\text { university }\end{array}$ & Unspecified & Bibliography & Unspecified & University & $\begin{array}{l}\text { (Dawe, } \\
\text { Vetter, \& } \\
\text { Martin, } \\
\text { 2004) }\end{array}$ \\
\hline $\begin{array}{l}\text { University } \\
\text { of Illinois - } \\
\text { Chicago }\end{array}$ & No & $\begin{array}{l}\text { The } \\
\text { university }\end{array}$ & Unspecified & Bibliography & Unspecified & University & $\begin{array}{l}\text { (Klein- } \\
\text { Banai \& } \\
\text { Theis, } \\
\text { 2011) }\end{array}$ \\
\hline $\begin{array}{l}\text { University } \\
\text { of } \\
\text { Newcastle }\end{array}$ & No & $\begin{array}{l}\text { Person who } \\
\text { is part of the } \\
\text { university }\end{array}$ & Unspecified & Bibliography & Unspecified & University & $\begin{array}{l}\text { (Flint, } \\
\text { 2001) }\end{array}$ \\
\hline $\begin{array}{l}\text { University } \\
\text { of Toronto } \\
\text { Mississaug } \\
\text { a }\end{array}$ & No & $\begin{array}{l}\text { Person who } \\
\text { is part of the } \\
\text { university }\end{array}$ & Unspecified & Bibliography & Unspecified & University & $\begin{array}{l}\text { (Conway } \\
\text { et al., } \\
2008 \text { ) }\end{array}$ \\
\hline $\begin{array}{l}\text { Willamette } \\
\text { University }\end{array}$ & No & $\begin{array}{l}\text { Person who } \\
\text { is part of the } \\
\text { university }\end{array}$ & Unspecified & $\begin{array}{l}\text { Bibliography \& } \\
\text { specialized } \\
\text { institutions }\end{array}$ & Unspecified & University & $\begin{array}{l}\text { (Willamett } \\
\text { e } \\
\text { University } \\
\text { Sustainabil } \\
\text { ity } \\
\text { Council, } \\
\text { 2008) }\end{array}$ \\
\hline
\end{tabular}

